\title{
Una visita al campo de concentración de Mauthausen en septiembre de 1992
}

Víctor Manuel Fernández Martínez | Dpto. de Prehistoria, Historia Antigua y Arqueología, Universidad Complutense de Madrid

URL de la contribución <www.iaph.es/revistaph/index.php/revistaph/article/view/5030>

En septiembre de 1992 viajé hasta Polonia para asistir en Poznan a un congreso de arqueólogos africanistas ${ }^{1}$. Fui acompañado de Alfredo Jimeno y Mario Menéndez, que dirigían conmigo las excavaciones prehistóricas de la Universidad Complutense en el Nilo Azul sudanés, cuyos primeros resultados íbamos a presentar allí. El viaje lo hicimos en mi Peugeot 309, turnándonos en la conducción desde Madrid a Polonia y luego la vuelta, una tarea agotadora incluso para personas todavía jóvenes como éramos entonces.

Tras el congreso decidimos darnos una pequeña vuelta por la Mittleeuropa, que apenas conocíamos y que acababa de salir del largo encierro de la Guerra Fría. Estuvimos en Berlín, que yo ya había visitado antes un par de veces; en Praga, que naturalmente nos fascinó; y en Viena, para volver luego atravesando larguísimas autopistas hasta Madrid. Antes de llegar a Praga nos detuvimos en Terezín, el antiguo cuartel barroco que había sido el gueto más "habitable" de todos los encierros que sufrieron los judíos europeos bajo los nazis. Los grandes edificios nos parecieron fríos y completamente vacíos, y apenas un museo que no recuerdo muy grande daba cuenta de aquella ignominia.

Unos días después, siguiendo el Danubio una vez dejada Viena, con la intención principal de visitar Hallstatt, el famoso yacimiento prehistórico de la Edad del Hierro donde nacieron los primeros celtas, paramos unas horas en el campo de Mauthausen. Allí estuvieron detenidas algo más de 300.000 personas entre 1940 y 1945, de las que solo unas 80.000 sobrevivieron. Que los historiadores todavía discutan estas cantidades aproximadas añade todavía más horror al espanto: decenas de miles de personas murieron sin dejar ninguna huella. De los presos republicanos españoles hay datos de la muerte de algo más de cinco mil.

El campo está sobre una elevación muy cerca del río, en un paraje de gran belleza como todos los que íbamos viendo en los rebordes alpinos austriacos. Si no recuerdo mal, dentro del lager había muy pocos visitantes, lo que nos permitió recorrer las instalaciones en silencio y con el corazón en un puño.

Antes de andar entre los barracones visitamos el museo, donde tras bajar unas escaleras había bastantes vitrinas con objetos y fotografías de la época. Una de ellas representaba a un interno (un "detenido", häftling) vestido con un traje roto y remendado. Su rostro hinchado mostraba que antes de la foto había sido golpeado brutalmente. Entonces recordé el capítulo que Claudio Magris dedica al campo en su insigne libro sobre el Danubio y que había leído poco antes. En él menciona la foto y afirma que aquel guiñapo de hombre mostraba mucha más dignidad en sus harapos que los atildados miembros de las SS que mandaban entonces, vestidos con su exagerada y ridícula guardarropía de teatro bufo. Hoy he buscado en la guía que compré entonces del campo y escaneado para reproducir aquí esa misma foto, cuyo pie dice únicamente "Prisionero cerca de la muralla de los lamentos, verano de 1944".

En otra de las vitrinas había uno de esos trajes de rayas como burdos pijamas que llevaban todos los presos. Lo que me impresionó de aquella ropa era que no se parecía a la que yo recordaba haber visto en las fotografías. Las bandas oscuras eran de un azul tan denso que era "casi negro" y las claras de un gris borroso, todo ello tal vez alejado del original por efecto de la suciedad. El 


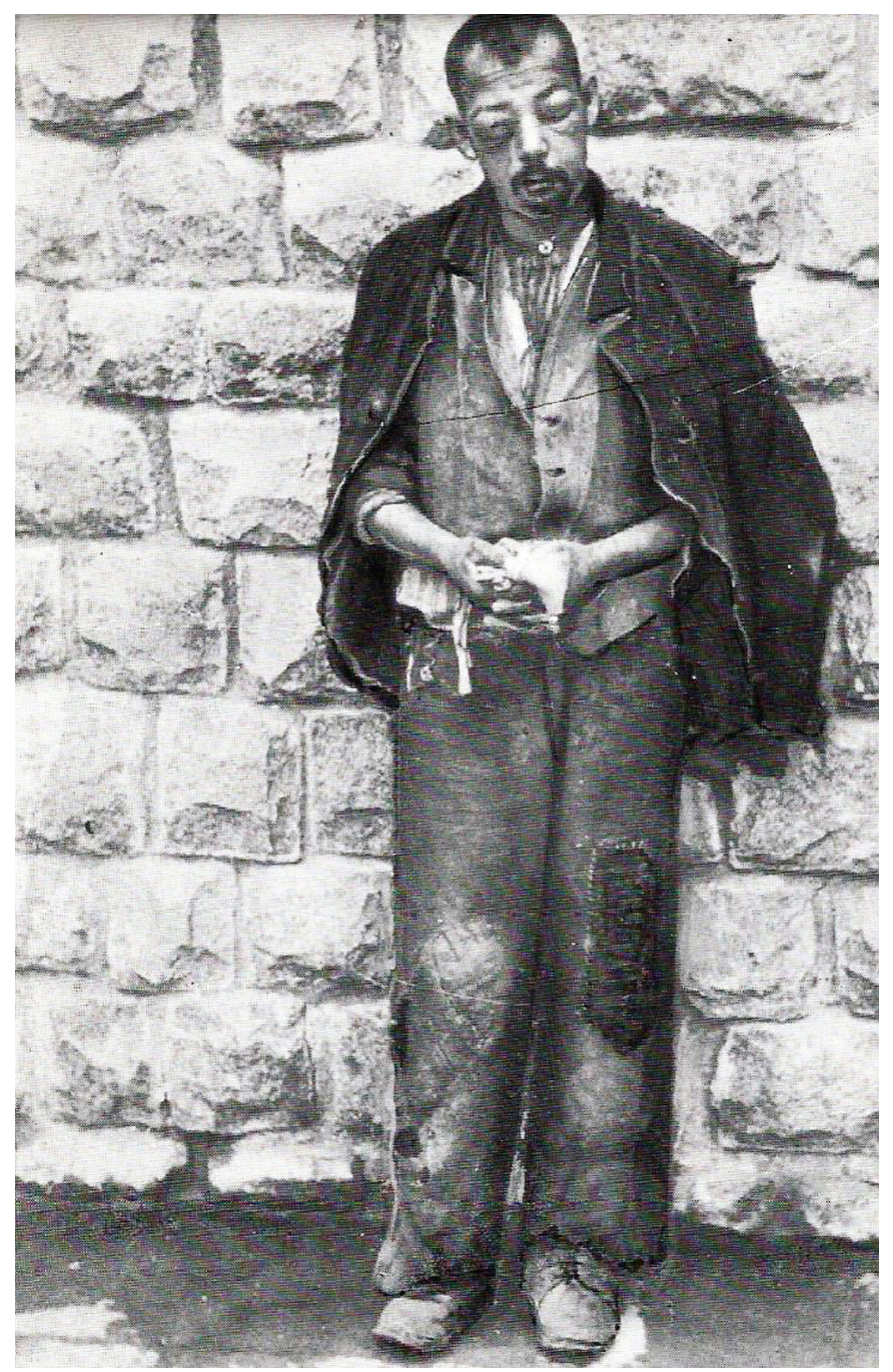

Prisionero cerca de la muralla de lamentos, verano 1944 | fuente Marsalek, H. Konzentrationslager Mauthausen. Wien: Österreichische Lagergemeinschaft Mauthause

resultado completo era algo que reducía a quienes lo llevaban a una especie de mancha flotando en el aire, tal vez el efecto degradante que se quería conseguir.

En el edificio central había una serie de celdas cuadradas a lo largo de un pasillo. Eran relativamente grandes y la información escrita decía que allí habían estado recluidos personajes importantes. En un momento dado, yo entré en una de ellas y la puerta se cerró sola, muy despacio, tras de mí. Entonces mi corazón dio un vuelco y casi salté a abrirla de nuevo, con una mezcla de alivio y de miedo al darme cuenta por un instante de lo que significaba estar allí dentro.

El exterior de la muralla de entrada, donde se tomaron las famosas fotos del momento de la liberación, estaba literalmente repleto de monumentos erigidos en memoria de los prisioneros, de muchas naciones y en muchas lenguas diferentes. Recuerdo que nos sorprendió y dolió que la única lápida española fuera una antigua, construida por la República en el exilio, y que no hubiera nada representando a nuestra democracia, tras diez años de gobierno socialista...

Un poco más allá de los monumentos empezaba la famosa "escalera de la muerte" que bajaba hasta la base de la gran cantera de donde los presos acarreaban diariamente grandes piedras en una subida eterna en la que muchos de ellos dejaban la vida por puro agotamiento.

En ese momento de final del verano todos los alrededores estaban cubiertos por una suave y verde hierba, y un poco más allá de la cantera se veían los edificios de varias granjas, formando una bucólica escena sobre el paisaje ondulado. No pude evitar pensar que esas granjas no parecían recientes y que debían de estar ya ahí durante la guerra, y que aquellos campesinos austriacos no solo conocían lo que pasaba dentro del campo, sino que casi lo podían presenciar en directo todos los días. También era difícil no quedar espantado ante esa combinación absurda del paisaje circundante, uno de los más bellos que he visto nunca, y el horror que tuvo lugar durante tantos años allí mismo...

\section{NOTAS}

1. Este texto fue redactado con motivo de la instalación de las placas de la memoria (Stolpersteine) de los deportados españoles en algunas calles de la capital. Madrid, abril de 2019. 